\%

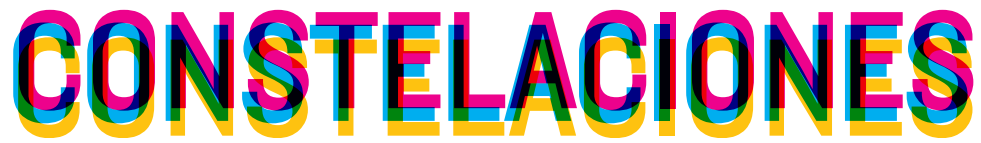

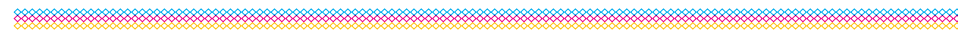


CONSTELACIONES n², mayo 2014

Revista de Arquitectura de la Universidad CEU San Pablo

Architecture Magazine of CEU San Pablo University

Periodicidad anual

Annual periodicity

COMITÉ DE REDACCIÓN EDITORIAL COMMITTEE

\section{Director Director}

Juan García Millán

Jefa de Redacción Editor in Chief

Covadonga Lorenzo Cueva

Secretario de Redacción Editorial Clerk

Rodrigo Núñez Carrasco

Maquetación y producción Design and production

María Fernández Hernández

Vocales Board Members

Fernando del Ama Gonzalo. Escuela Politécnica Superior, Universidad CEU San Pablo, Madrid

Pablo Campos Calvo-Sotelo. Escuela Politécnica Superior, Universidad CEU San Pablo, Madrid

Alfonso Díaz Segura Escuela Superior de Enseñanzas Técnicas, Universidad CEU Cardenal Herrera, Valencia

Mayka García Hípola. Escuela Politécnica Superior, Universidad CEU San Pablo, Madrid

Sonia Izquierdo Esteban. Escuela Politécnica Superior, Universidad CEU San Pablo, Madrid

Javier Sáenz Guerra. Escuela Politécnica Superior, Universidad CEU San Pablo, Madrid

\section{CONSEJO EDITORIAL EDITORIAL BOARD}

Beatriz Colomina. School of Architecture, Princeton University, New Jersey

Carmen Díez Medina. Escuela de Ingeniería y Arquitectura, Universidad de Zaragoza

María Antonia Frías Sargadoy. Escuela Técnica Superior de Arquitectura, Universidad de Navarra

Ángel González García. Facultad de Geografía e Historia, Universidad Complutense de Madrid

Juan Miguel Hernández Léon. Escuela Técnica Superior de Arquitectura, Universidad Politécnica de Madrid

Juan José Lahuerta Alsina. Escuela Técnica Superior de Arquitectura, Universidad Politécnica de Cataluña, Barcelona

Eduardo Leira Sánchez. Ex director del Plan General de Ordenación Urbana, Madrid

Joaquín Medina Wamburg. Facultad de Aquitectura Diseño y Urbanismo, Universidad de Buenos Aires

Zaida Muxí Martínez. Escuela Técnica Superior de Arquitectura, Universidad Politécnica de Cataluña, Barcelona

José Joaquín Parra Bañón. Escuela Técnica Superior de Arquitectura, Universidad de Sevilla

Víctor Pérez Escolano. Escuela Técnica Superior de Arquitectura, Universidad de Sevilla

Fernando Pérez Oyarzún. Escuela de Arquitectura y Diseño, Pontificia Universidad Católica, Santiago de Chile Judith Sheine. School of Architecture and Allied Arts, University of Oregon, Portland

Andrés Walliser Martínez. Global Design, New York University, Nueva York

\section{ISSN 2340-177X}

Depósito legal M-13872-2013

(c) de los textos, sus autores

(c) de las imágenes autorizadas

(c) Revista Constelaciones

๑) Escuela Politécnica Superior, Universidad CEU San Pablo

Universidad CEU San Pablo

Escuela Politécnica Superior

Urbanización Montepríncipe, $s / n$

Boadilla del Monte, 28668. Madrid (España)

constelaciones@eps.ceu.es

www.uspceu.es

Edición Edition

Fundación Universitaria San Pablo CEU

Madrid, España

Impresión Printing

VA Impresores

Impreso en España Printed in Spain

Distribución Distribution

CEU Ediciones

Los textos que componen Constelaciones se obtienen mediante convocatoria pública. Para que los trabajos recibidos entren en el proceso de selección de los artículos a publicar deben ser trabajos originales no publicados anteriormene, con una extensión recomendada de 3.000 palabras, título, resumen (un máximo de 150 palabras) y palabras clave (un mínimo de cuatro palabras), en español y en inglés. Tras haber cumplido estos requisitos (y los correspondientes incluidos en las normas editoriales de la revista, disponibles para consulta en formato digital desde el comienzo de la convocatoria), tiene lugar un proceso de revisión y evaluación de los artículos previa aceptación de los mismos para su publicación. Para acometer dicho proceso, y con el fin de asegurar la calidad de los contenidos, la Revista Constelaciones recurre a evaluadores externos a la institución editora y anónimos (cada artículo es evaluado por dos de ellos) encargados de someter a crítica los mismos. Todos los artículos de investigación publicados en esta revista han pasado por dicho proceso. La recepción de artículos se extendió hasta el 30 de Septiembre de 2013. Texts included in Constelaciones are obtained by public announcement. Only original papers that have not been previously published will be included in the process of selection of articles. They should not exceed 3.000 words and should include a title, an abstract (no more than 150 words) and keywords (a minimum of four words), in Spanish and English. After having fulfilled these requirements (and those included in magazine editorial standards, available for consultation from the beginning of the Call for Papers), occurs a process of review and evaluation of articles upon acceptance of them for publication. To undertake this process, and in order to ensure the quality of the contents, Constelaciones turns to external and anonymous evaluators to the institution (each article is evaluated by two of them) responsible for the critic. All the articles published in this journal have undergone this process. The deadline for reception was extended until September 30, 2013.

Todos los derechos reservados. Esta publicación no puede ser reproducida, ni en todo ni en parte, ni registrada, ni transmitida, ni almacenada en ningúna forma ni por ningún medio, sin la autorización previa y por escrito del equipo editorial. En este número se han utilizado algunas imágenes de las que no se ha podido identificar al propietario de los derechos. En estos casos hemos entendido que las imágenes son de libre uso. En caso de identificar alguna de estas imágenes como propia, por favor, póngase en contacto con la redacción de Constelaciones. Los criterios expuestos en los diversos artículos de la revista, son responsabilidad exclusiva de sus autores, y no reflejan necesariamente los que pueda tener el equipo editoral. El equipo editorial de la revista no se responsabiliza de devolver la información enviada a la redacción a no ser que se le solicite expresamente. All rights reserved. This publication cannot be reproduced, in whole or in part, nor registered, transmitted or stored in any form or by any means, without the written permission of the Editorial team, In this issue some images were used without knowing the owner of the rights. In these cases, we have understood that the images are free of use. In case you identify written permission of the Editorial team, In this issue some images were used without knowing the owner of the rights. In these cases, we have understood that the images are free of use. In case you identify
any of these images as your own, please, contact with the Editorial staff of Constelaciones. The opinions expressed in this issues's articles are entirely the responsibility of their authors and are not necessarily shared by the editors of this journal. The publisher don't take responsibility for returning submitted material which is not expressly requested. 


$$
11
$$




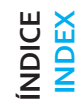

$\stackrel{n}{\sim}$

ร

5

$\curvearrowright$

๙ิ

$\stackrel{n}{=}$

$\bar{m}$
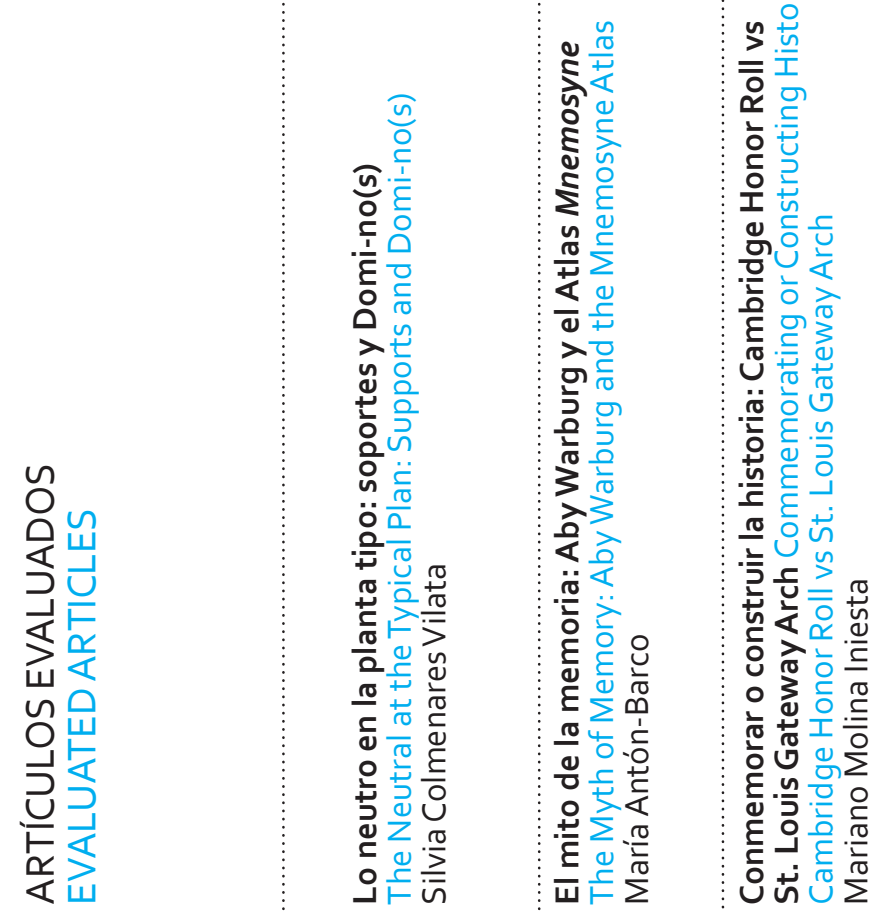

旁 을

‥

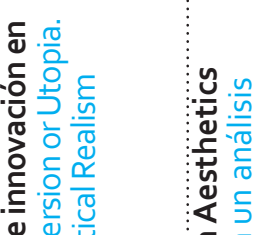

앙

胥苞

$\bar{\Psi}$

宛

일

능홍

区告

음 흠

응 흥

\%

든

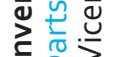

ข

음

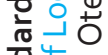

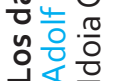

a व

은

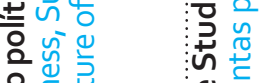

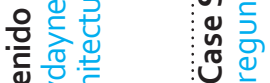

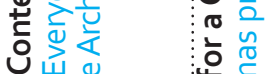

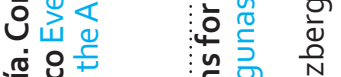

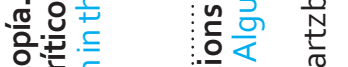

गे

गे० गे ये ज

:

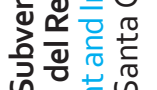

है

ज०

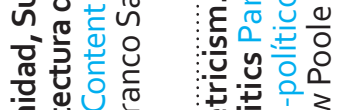

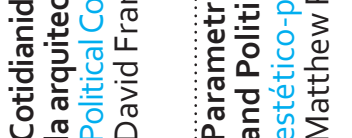

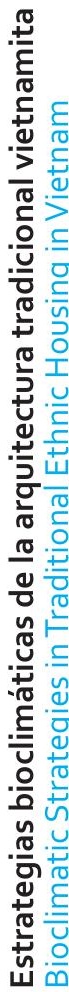

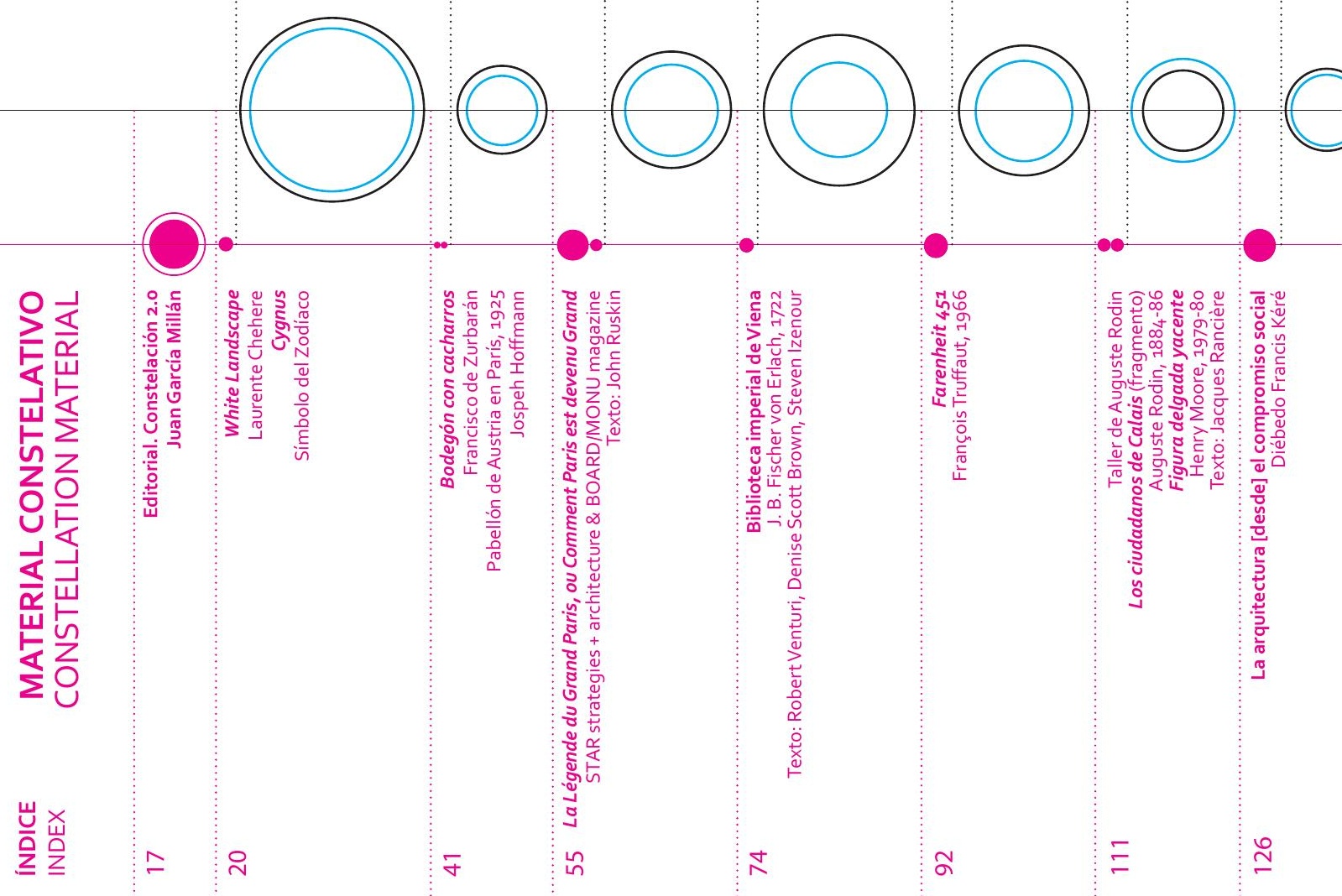

苍

० 


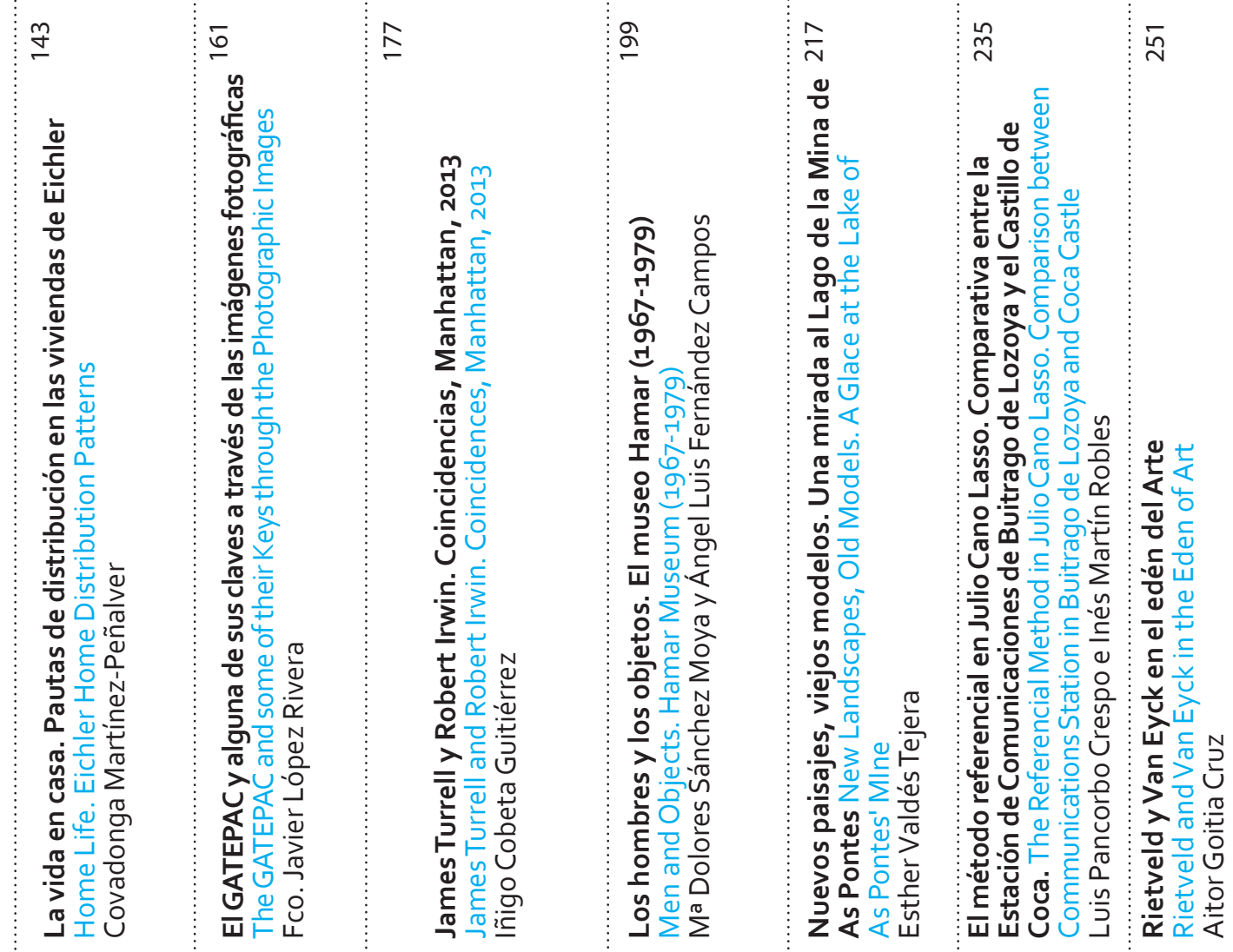
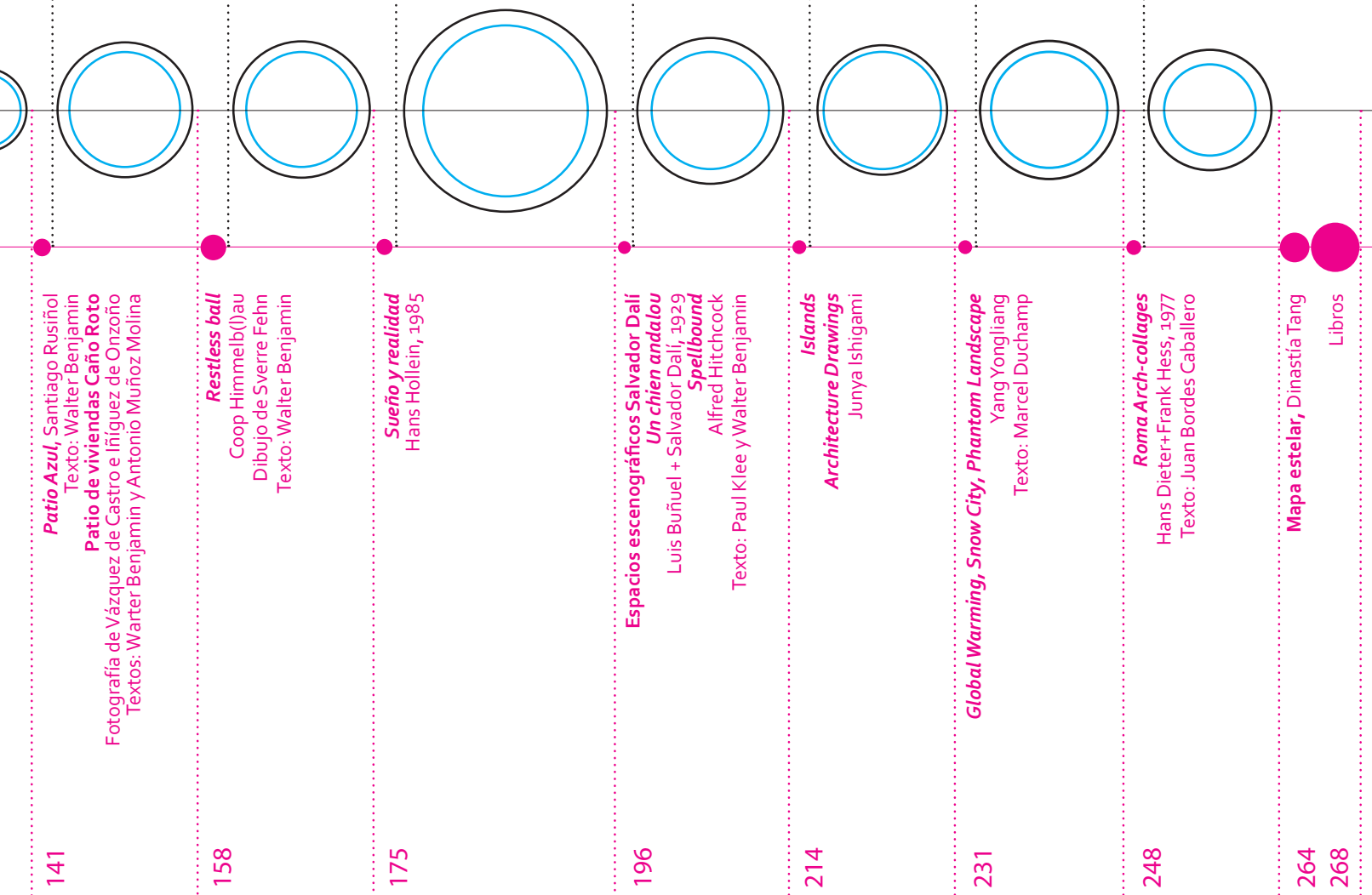


\section{El método referencial en Julio Cano Lasso.}

\section{Comparativa entre la Estación de Comunicaciones de Buitrago de Lozoya y el Castillo de Coca.}

The Referential Method in Julio Cano Lasso. Comparison between Communications Station in Buitrago de Lozoya and Coca Castle

Luis Pancorbo Crespo e Inés Martín Robles

Escuela Técnica Superior de Arquitectura, Universidad Politécnica, Madrid.

Traducción Translation Luis Pancorbo Crespo, Inés Martín Robles

\section{Palabras clave Keywords}

Arquitectura española, Cano Lasso, referencia, tradición, teoría, metodología

Spanish Architecture, Cano Lasso, reference, tradition, theory, methodology

\section{Resumen}

La producción de Julio Cano se presenta como 'ecléctica' por parte de la crítica arquitectónica de su época debido a la variedad de respuestas que ofrece a distintos problemas. Esto es producto de la actitud de Cano, que propone la disolución de la importancia del arquitecto como 'autor' de una arquitectura, rechazando la utilización de un estilo propio -un idiolecto arquitectónico - y en cambio, dando protagonismo precisamente al propio método proyectual.

El objetivo del artículo es analizar su método proyectual y buscar relaciones de su obra con referencias exteriores que nos ayuden a ejemplificar lo que hemos denominado 'método referencial', dentro del método proyectual global del arquitecto. Se utiliza el análisis comparativo a distintos niveles entre la Estación de Comunicaciones por Satélite de Buitrago de Lozoya y el Castillo de Coca para detectar uno de los archipiélagos de referencias más comunes en Cano, la referencia a la ruina.
Abstract

Julio Cano's work is presented as 'eclectic' by architectural critics of his time because of the variety of answers offered to various issues. This is a result of Cano's attitude, who proposed the dissolution of the importance of the architect as 'author' of architecture. Rejecting the use of an own style, an architectural idiolect, and instead giving prominence precisely to the design method itself.

The aim of the article is to analyze Julio Cano's design method and to find the relationship between his work and some external references, so to help us illustrate what we have called 'reference method' in the overall project methodology of the architect. Comparative analysis at different levels between the Satellite Communications Station, in Buitrago de Lozoya and Coca Castle is used to detect one of his most common constellation of references; the reference to ruins. 
"El innovador es guía que no sigue el rastro, pero conoce los viejos caminos"

"The innovator is guide that not follow the trail but knows the old ways"

SHKLOVSKI, Viktor. La cuerda del arco.

Julio Cano Lasso. Poética Arquitectónica. (1) Cano Lasso ocupa, frente a otros arquitectos coetáneos, una posición singular que algunos críticos como Antón Capitel (2) o Juan Daniel Fullaondo, (3) en los noventa, califican de 'ecléctica', pero vista desde el contexto actual se revela como la más coherente, clara y contemporánea de todas. En su producción se hace notar una constante evolución formal, circunscrita siempre a un marco metodológico y teórico bien delimitado. No se da en ella una trayectoria tan diversa y brillante como la de Sáenz de Oíza, ni el monolitismo esencial y extremadamente depurado de Sota. Según aclara Capitel en su artículo 'Notas sobre la figura de Julio Cano Lasso en la arquitectura española', Cano se adscribe a una actitud de carácter mucho más moderado, moderación armada con una poderosa sensibilidad plástica, además de con una pericia y sensatez profesional capaz de sopesar y medir la adecuación al tema y al lugar y elegir y mezclar en consecuencia sus recursos. En uno de los pocos textos teóricos que produjo y que irá reelaborando constantemente durante toda su vida, (4) Cano explicita una metodología proyectual extremamente concisa que evita la búsqueda apriorística del resultado final determinado y prima el proceso propio de creación arquitectónica frente a la necesidad de reconocimiento de "la mano del autor" en la materialización formal. Lo importante es el proyecto, no el arquitecto.

Partiendo de una vasta base cultural, que contiene tanto la arquitectura tradicional como la del Movimiento Moderno en cuanto a sus procesos y conceptos generadores, en el momento de empezar el proyecto hace tabula rasa ocupándose exclusivamente del contexto concreto y de unos principios generales: relación con el entorno, racionalidad y economía constructiva, elección de la tecnología adecuada, sensibilidad y rigor en el empleo de los

Julio Cano Lasso. Architectural Poetic. (1) Cano Lasso ranks, compared to other coeval architects, a unique position that some critics as Antón Capitel (2) or Juan Daniel Fullaondo (3) in the nineteen nineties described as "eclectic", but viewed from the current context is revealed as the most coherent, clear and contemporary of all. His production is clearly a constant formal evolution always confined to a well-defined methodological and theoretical framework. It is not given such a diverse and brilliant trajectory as in Sáenz de Oíza neither the essential and extremely depurated Sota’s monolithism.

As Capitel clarifies in his article 'Notes on the Figure of Julio Cano Lasso in Spanish Architecture', Cano is ascribed to an attitude of more moderate character, moderation armed with a powerful plastic sensibility, plus a professional expertise and a wisdom capable to weigh and measure the appropriateness to the theme and the place, and accordingly choose and mix their resources. In one of his few theoretical texts, constantly reworked during his lifetime, (4) Cano explicit an extremely concise project methodology that avoids an 'a priori' determined pursuit of the ultimate result and favors the process of architectural creation against the need to recognize "the author's hand" in the formal realization. What is important is the project, not the architect.

From a vast cultural base, which contains both the traditional architecture and the Modern Movement regarding their processes and generating concepts, at the time of starting the project, Cano does tabula rasa dealing 
materiales y colaboración con la naturaleza. No supone una disolución de la autoría de raíz estructuralista o como la formulada por Michel Foucault o Roland Barthes, sino más bien una puesta 'en su sitio' del papel del autor similar a la realizada por Igor Stravinski: (5) "No pienso negar a la inspiración el papel eminente que se le otorga en la génesis que estudiamos; simplemente afirmo que no es en modo alguno condición previa del arte musical, sino una manifestación secundaria en el orden del tiempo".

La tensión entre su adscripción al Movimiento Moderno, con su discurso de racionalidad y eficacia, y la valoración de la tradición como fuerza profunda y de continuidad, se mantienen a lo largo de toda su evolución profesional. En 'Mi visión de la arquitectura' (4) propone un acercamiento a la tradición de tipo metodológico y racional. Cano podría seguramente suscribir las palabras de Aldo Van Eyck en El interior del tiempo: (6) "Me parece que pasado, presente y futuro deben estar, como un continuo, activos en el interior de la mente. Si no es así, los artefactos que hagamos carecerán de profundidad temporal, de capacidad de asociación". Todo esto se refleja en una obra, que se hace más compleja, según la diversidad de problemas a resolver y que lo que tiene de evocadora de las arquitecturas tradicionales se produce como consecuencia lógica del laborioso proceso proyectual, que siempre partiendo de la contemporaneidad y de presupuestos racionalistas, podríamos denominar 'creación referencial.' (Fig. 1)
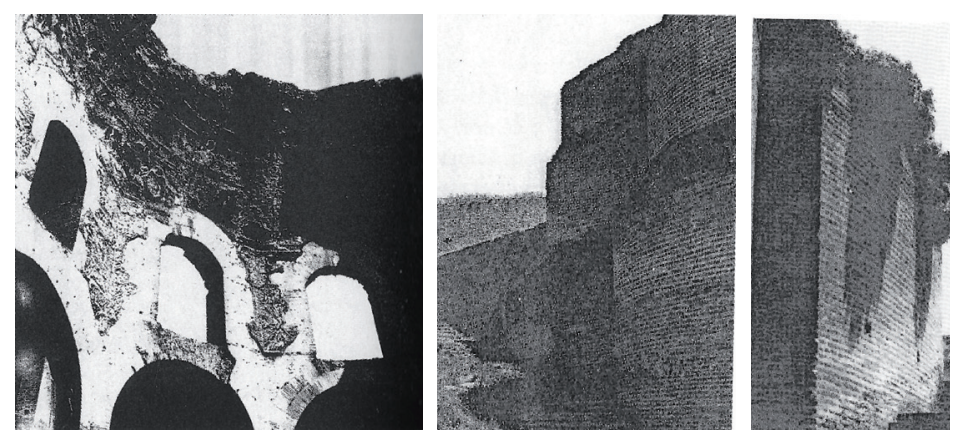

Fig. 1. Referencias a ruinas de Julio Cano Lasso.

exclusively the specific context and some general principles: relationship with the environment, economy and constructive rationality, choosing the right technology, sensitivity and rigor in the use of materials and collaboration with nature.

It does not imply a dissolution of the authorship of structuralist root or as formulated by Michel Foucault and Roland Barthes, but rather a putting 'in place' the role of the author similar to that explained by Igor Stravinsky: (5) "I will not deny to the inspiration the prominent role given in the genesis we are studying; simply say that it is by no means a prerequisite to the musical art but a secondary manifestation in the order of time".

The tension between his allegiance to the Modern Movement, with its discourse of rationality and efficiency, and the valuation of tradition as a deep and continuous force are maintained throughout the whole of his professional career. In 'My vision of Architecture' (4) proposes an approach to the tradition of methodological and rational type. Cano would surely endorse the words of Aldo Van Eyck in The interior of the time: (6) "I believe that past, present and future should be, as a continuous, active within the mind. If not, the artifacts we make will lack temporal depth and association capacity". 


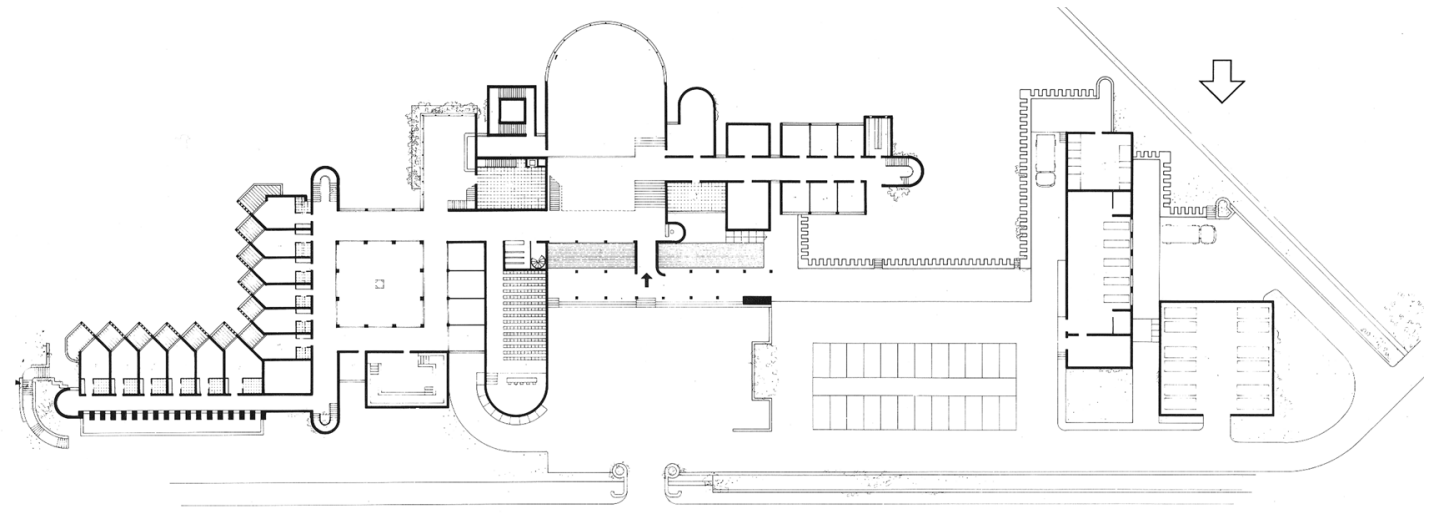

La anterior reflexión sobre el método proyectual de Cano se ve ilustrada con el ejemplo de la Estación de Comunicaciones por Satélite de Buitrago Fig. 2. Planta de la Estación de Comunicaciones por Satélite, Buitrago de Lozoya. de Lozoya (Madrid), (Fig. 2) de 1967 -en colaboración con Juan Antonio Ridruejo- en la que el uso del ladrillo sirve de medio para entablar diálogo con las arquitecturas históricas y más concretamente con el Castillo de Coca (Segovia), desde un nivel no sólo constructivo sino también desde otro más esencial; el de las estrategias y conceptos generadores del proyecto y responsables por tanto de su formalización.

Para situar el proyecto de Buitrago, la obra es posterior a las viviendas en la calle Espalter y Bailén, y las unifamiliares de sus inicios; es del mismo año que el inicio del proyecto de las viviendas de la calle Basílica y anterior a las centrales telefónicas, los edificios de las viviendas de protección oficial y las universidades laborales.

La Estación de Comunicación por Satélite de Buitrago. En su cuento 'Pierre Menard, autor del Quijote', J.L. Borges nos explica cómo P. Menard intentó ponerse en el lugar de Cervantes y escribir el Quijote, siendo él mismo, hombre del siglo xx con sus experiencias, sistema de pensamiento y conocimientos. En el texto de Borges se produce una comparación entre dos

All this is reflected in a work that becomes more complex, according with the diversity of problems to solve and that evokes traditional architectures as a logical consequence of the painstaking design process, always starting from contemporary and rationalist assumptions, that we could call 'referential creation'. (Fig. 1)

The previous reflection on Cano's design method is illustrated with the example of Satellite Communications Station in Buitrago de Lozoya (Madrid), (Fig. 2) 1967 -in collaboration with Juan Antonio Ridruejo- where the use of brick serves as a way to engage in dialogue with historical architectures, and more specifically with the Coca Castle (Segovia), not only from a constructive level but also from a more critical one; from the design strategies and concepts, responsible of its formalization.

To place this project in time, Buitrago follows the housing buildings in Espalter Street and Bailen Street, both in Madrid, and his first single house projects, and coincides with the beginning of the works of the housing building in Basílica Street, also in Madrid. It precedes the Telephone Exchange Buildings, the P.P.O Buildings and the Labor Universities.

Satellite Communication Station in Buitrago de Lozoya. In his story 'Pierre Menard, Author of the Quixote', J.L. Borges explains how P. Menard tried to take the place of Cervantes and write Don Quixote being himself, a man of the $\mathrm{xx}$ 
fragmentos del Quijote, uno de Cervantes y otro de Menard, textualmente idénticos, pero interpretados de manera distinta en función de la intención y circunstancias del autor; el de Cervantes como "elogio retórico de la historia" en tanto que el de Menard se extrae la consideración de "la historia como madre de la verdad". (7)

En la obra de Buitrago, es evidente la evocación de la arquitectura del Castillo de Coca, (Fig. 3) como el mismo autor nos cuenta en varios textos. (8) Es ésta una relación no buscada, sino encontrada. Igual que Menard, Cano la obtiene desde presupuestos contemporáneos y como resultado de una labor de análisis del lugar y del programa totalmente racionalista. Hay coincidencia en las formas aunque no en la esencia; en cambio, hay algunas estrategias a nivel proyectual que tienen relación en el proceso de creación de ambos edificios como son:

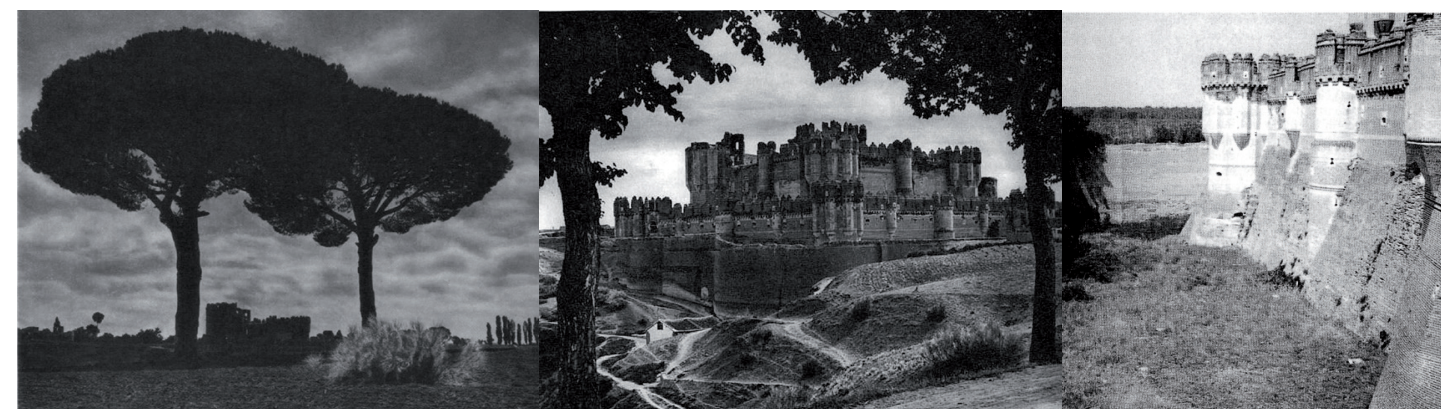

1. Adaptación a la topografía. 'Alamboramiento'. El Castillo de Coca se Fig. 3. Castillo de Coca. sitúa en una barranca abierta al valle formado por dos ríos, aprovechado las características topográficas, el edificio se asienta dentro de un profundo y ancho foso, es lo que se denomina un castillo 'alamborado. Esta estrategia permitió la construcción de un castillo de altura suficiente para evitar el asalto por escalada y a la vez presentar un perfil bajo a cierta distancia, lo que evitaba que fuese un blanco fácil para el fuego de artillería.

Century with his experiences, thoughts and knowledge system. There is a comparison in Borges' text between two fragments of Don Quixote, one of Cervantes and the other one of Menard, textually identical but differently interpreted according to the purpose and circumstances of the author; the Cervantes one as "rhetorical praise of history" and Menard's one as "history as the mother of truth". (7)

In Buitrago, the evocation of the architecture of the Coca Castle is clear, (Fig. 3) as the author tells us in several texts. (8) This is not an intended rather than found relationship. As Menard, Cano obtains it from contemporary budgets and as a result of a fully rationalistic form of analytical work on program and place. There is coincidence in the forms but not in the essence; however, there are some similar strategies related to proyectual level in the process of design of both buildings such as:

1. Adjustment to topography. 'Moating. Coca Castle lies in an open valley canyon formed by two rivers, it takes advantage of topographic features, the building sits in a deep and wide moat, it can be defined as a 'moated' castle. This strategy allowed the construction of a castle of sufficient height to prevent the assault by climbing and showing simultaneously a distant low profile to prevent from being an easy target for artillery fire.

In Buitrago, ditches, slopes and retaining walls causes a reduction in scale of the building towards the entrance road, that 
En Buitrago, fosos, taludes y muros de contención causan una reducción de escala del edificio hacia la carretera por la que se produce el acceso, casi como medida de protección frente a ésta y como medio de adaptación al terreno, minimizando el movimiento de tierras y por tanto, el impacto sobre el territorio. (Figs. 4, 5)

2. Integración con el paisaje. Cano conoció el Castillo de Coca antes de su restauración, como ruina, y su valoración del edificio respecto a su integración paisajística se apoya en ese hecho. En Coca, el castillo se impone al paisaje y el paso del tiempo y la acción de la naturaleza lo integra y une con él, gracias al noble envejecimiento del ladrillo.

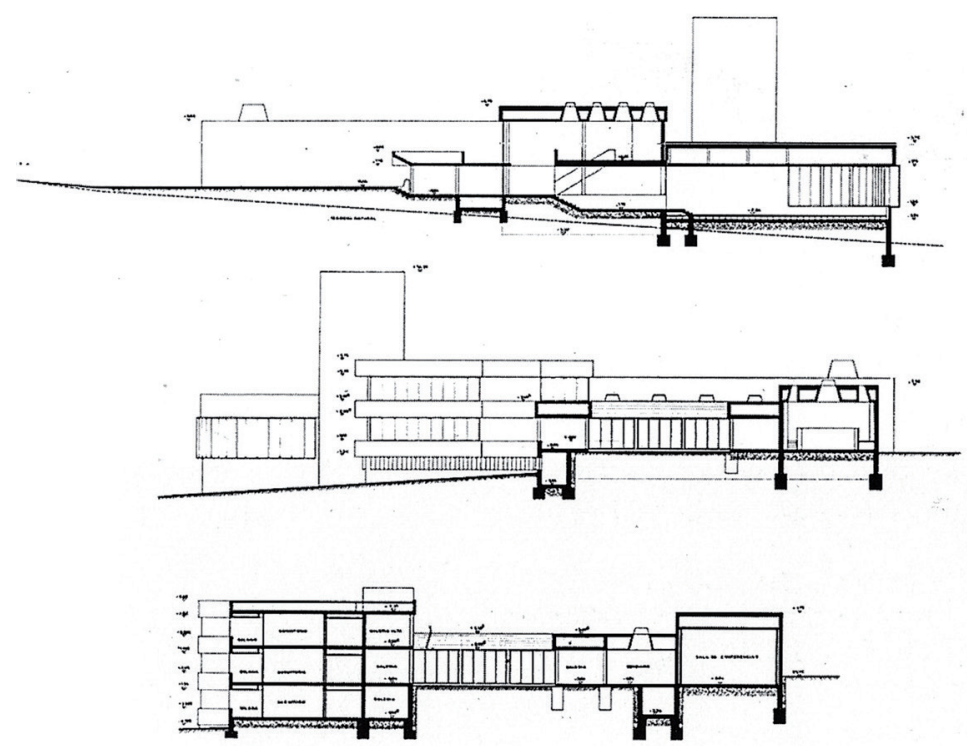

Fig. 4. Secciones transversales de la Estación de Comunicaciones por Satélite de Buitrago de Lozoya.

is almost a protection against it. It is also a way of adaptation to the ground, minimizing earthwork and therefore the impact on the territory. (Figs. 4, 5)

2. Integration with the landscape. Cano knew Coca Castle before restoration, in ruins, and his assessment of the building regarding to landscape integration relies on that fact. In Coca, the castle is imposed on the landscape, but over time the action of nature had integrated and blurred it with the territory thanks to the noble aging of brick.

Referring to Buitrago, the author explains his emphasis on the total unity of the material, insisting in the use of brick to their fullest potential and the rooting of the building on the ground "with the intention that the whole building seemed to grow from the land in the same way that piles of brick in a tile manufacture". (9) The variety of the program and the desire to articulate clearly each part of it in the composition, results in a decomposition of the plan (influenced by Alvar Aalto's architecture) and in a volumetric variety that could have endanged the unity of architecture, without the unifying force of the brick insistently and massively used that melts it with the territory.

3. Access path. Coca Castle is located in a corner of the walled area of the town, but the original entrance, with an access 

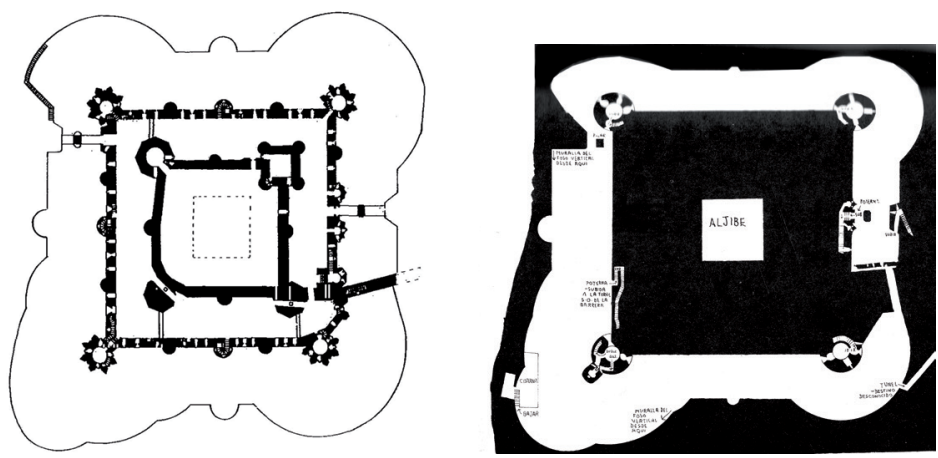

Fig. 5. Plantas del Castillo de Coca.

Refiriéndose a Buitrago, el autor explica su especial énfasis en la unidad total del material, insistiendo en el empleo del ladrillo al máximo de sus posibilidades y en el enraizamiento de la edificación en el terreno "con la intención de que el conjunto de edificaciones pareciera salir de la tierra de la misma forma que los rejales de ladrillo en los tejares". (9) La variedad del programa y el deseo de expresar claramente cada parte en la composición da lugar a una descomposición de la planta (influida por la arquitectura de Alvar Aalto) y a una variedad volumétrica, que hubiera podido poner en peligro la unidad de la arquitectura, si no hubiese sido por la fuerza unificadora del ladrillo utilizado de manera insistente y masiva, que lo funde con el territorio.

3. Recorrido de acceso. El Castillo de Coca se encuentra en una esquina del recinto amurallado de la villa, pero la entrada original, con acceso en puente, se encuentra al otro lado de la población obligando a un recorrido por el borde del foso a lo largo de los dos flancos en los que se situaba una mayor potencia de artillería. El acceso al castillo se reduce al mínimo, no se explicita, ya que es un punto débil en el sistema defensivo.

En Buitrago, al acceder desde la carretera en coche, se orienta la circulación hacia la gran antena que da sentido al complejo, y una vez se ha estacionado, la entrada al edificio se produce de manera tangencial, a través de la parte superior de los muros de contención y posteriormente, por debajo

bridge lies on the other side of town, forcing a tour along the pit edge where stood the flanks with a higher artillery power. Access to the Castle is minimized, is not explicit, as it is a weak point in the defense system.

In Buitrago, to access from the road by car, the movement is oriented towards the large antenna that gives meaning to the complex, and once the car has been parked, the entrance to the building occurs tangentially through the top of the retaining walls and subsequently under a portico half-submerged along a pond to be crossed by a bridge. Access is fully hidden from the view of people entering to the complex and it is reached after a studied tour whereby the visitor is introduced progressively in a number of spaces, open, bounded, semi-closed and closed. (Figs. 6-10)

Formal aspects, the choice of material. Use of brick is justified in Buitrago by purely practical criteria, to be the most economical material that allowed meet deadlines of work, due to its simplicity of execution. The same use of brick is determined in the case of Coca, because of its situation in a geological area of sedimentary character with a lack of stone.

Moreover, the use of brick in Buitrago responds to the rejection of an architectural expression based on technology, which could bring out the limitations and shortcomings of the construction techniques of the time. Also responds to the search of a certain tension between the role of a technologically advanced Central and an ancient material as brick. The opposite 


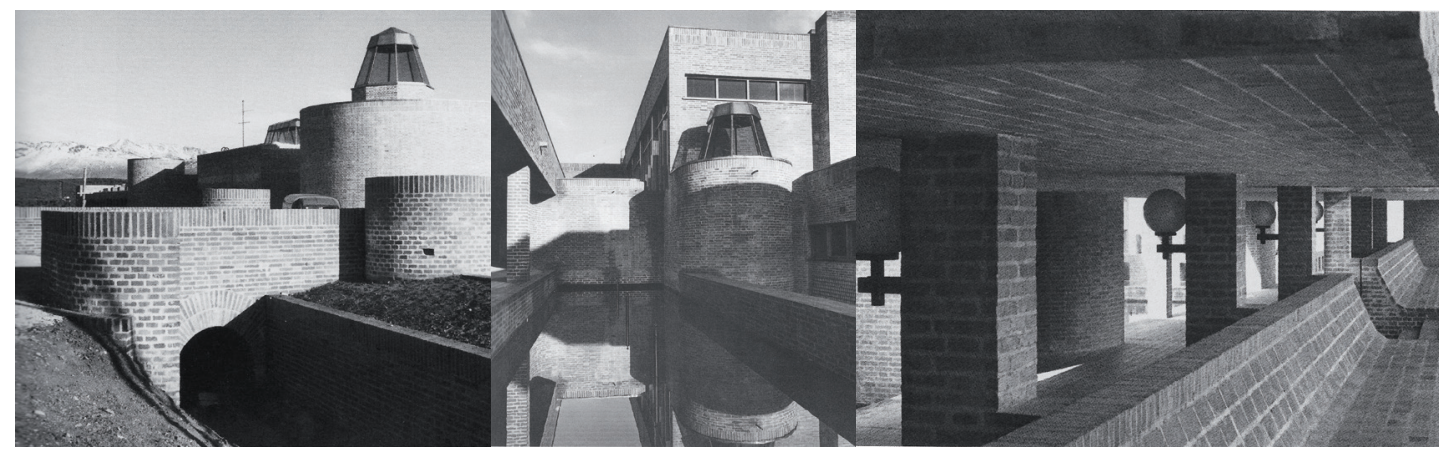

de una galería porticada semihundida a lo largo de un estanque que hay que salvar por medio de un puente. El acceso se encuentra así totalmente escamoteado de la vista del que accede al complejo y se llega a él después de un estudiado recorrido, que va introduciendo al visitante de manera progresiva en una sucesión de espacios abiertos, acotados, semicerrados y cerrados. (Figs. 6-10)

Aspectos formales, la elección del material. Esta elección se justifica por criterios puramente prácticos, en el caso de Buitrago, al ser el material más económico que permitía cumplir con los plazos de obra -por su sencillez de ejecución- y viene determinada, en el caso de Coca, por encontrarse en una zona geológica de carácter sedimentario con falta de piedra.

Por otra parte, el uso del ladrillo en Buitrago responde al rechazo de una expresión arquitectónica basada en lo tecnológico, que podría poner en evidencia las limitaciones y deficiencias de las técnicas constructivas de esa época y por la valoración de la tensión existente entre la función tecnológicamente avanzada de la central y algo tan antiguo como la construcción de ladrillo. El caso contrario ocurre en Coca, que aparece como el máximo exponente de la tecnología de su época, con un alarde en el uso del ladrillo tanto para el cumplimiento de su función defensiva como representativadecorativa asociada al uso como casa-palacio. (Fig. 11)

Figs. 6, 7 y 8. Recorrido de acceso
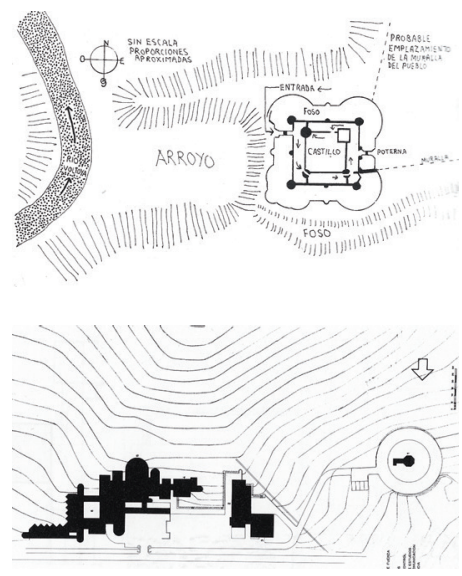

Fig. 9 Planta de situación de la Estación de Comunicaciones por Satélite de Buitrago de Lozoya.

Fig. 10. Esquema de situación del Castillo de Coca.

occurs in Coca, that appears as the exponent of the highest technology of its time, with a display in the use of brick for both fulfilling its roles as defensive building and as representative use as a palace. (Fig. 11) Constructive decisions in Buitrago are on the basis of the design. The shapes and volumes arise from solving real problems arising from the program, they meet a functional requirement. (Figs. 12,13)

1. Wall and hollow. Buitrago, despite its composed floor plan, with an association strategy of separate volumes, is presented from the access road as a walled building, born of the earth itself, impenetrable, solid and fortified. Like Coca Castle, is protected from hostile outside -from open space- and opens inward. Buitrago seems to protect nature from human action, closing the humanized side of the road (moating in relation to that level) and opening towards the valley, introducing natural landscape inside the building.

Cano used this strategy since his early works. His own House in La Florida (1955-1958) is dramatically closed to the street with whitewashed brick walls blind and opens seeking smoother interior-exterior relationship with the garden and with the patios enclosed in the building. The following text is very revealing of this attitude, that reminds of Voltaire's Candide conclusion: "My main hobbies are history, drawing and cultivating the garden. Because I love Nature, I try not to leave my house, so I advise to all those who truly love her".(10) (Figs. 14-17) 
Las decisiones constructivas se encuentran, en Buitrago, en la base del proyecto. Las formas y volúmenes nacen de la solución de problemas reales derivados del programa; responden a un requerimiento funcional. (Figs. 12, 13)

1. Muro y hueco. Buitrago, a pesar de su planta compuesta con una estrategia de macla de volúmenes independientes, se presenta desde la carretera de acceso como un edificio mural, nacido de la propia tierra, infranqueable, sólido, fortificado. Igual que el Castillo de Coca, se protege del exterior hostil -del espacio abierto- y se abre hacia su interior.

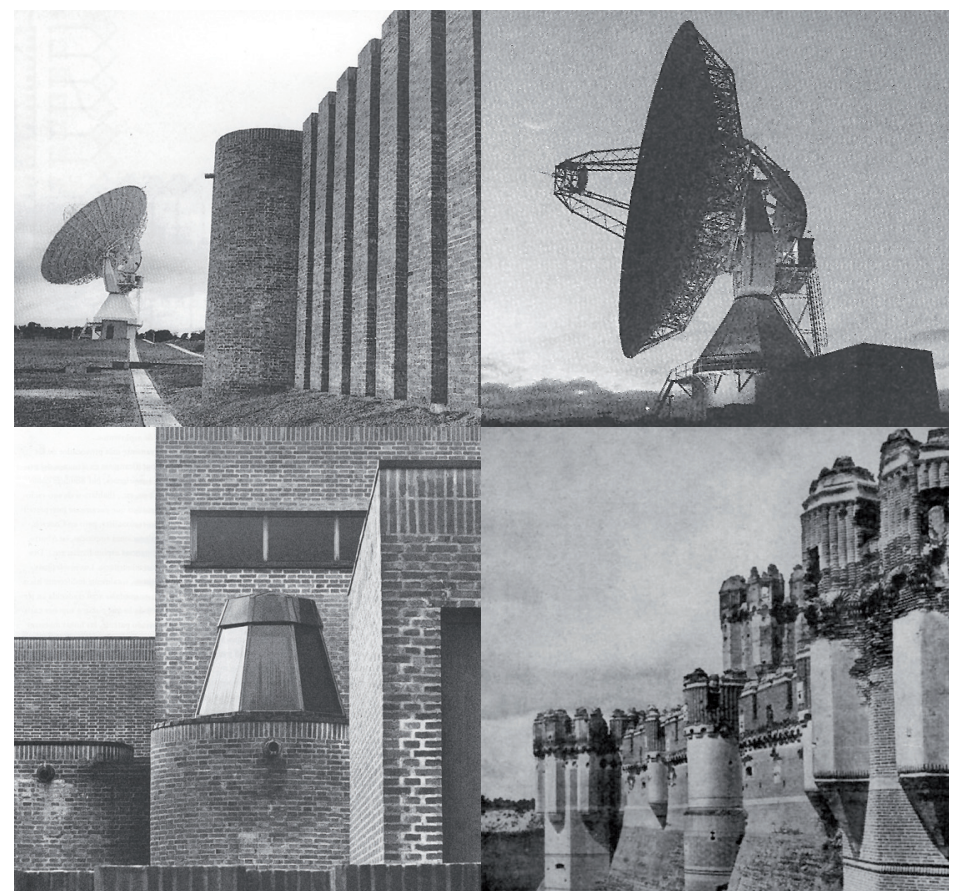

Fig. 11. Antena principal de la Estación de Comunicaciones por Satélite de Buitrago de Lozoya.

Figs. 12, 13. Comparativa de cuerpos poligonales.

2. The horizontal surfaces. In Cano's building the material uniformity is extreme, featuring similar landscape integration to that offered by the Coca Castle (paradoxically it corresponds to the appearance of a ruin, because in its time the castle had a very different appearance because of the profusion of ornamentation overlaying the walls). This desire to solve all the surfaces with the same material extends both vertically and horizontally: "The principle of the unity of the material is strictly followed, pushing to the limits of the possible the walls, floors, and stairs". (11) (Fig. 18)

3. The courtyard. The Coca yard, today nonexistent, is described by Pascual Madoz: (12) "consisted of a square courtyard with a double marble colonnade of Corinthian and Composite order, with tiled floors and walls". The main courtyard of Buitrago, which serves as a residence and study center, has one floor and a glazed perimeter gallery. The steel structure is part of the glass plane enclosure, almost blending into the vertical lines of window frames. (Figs. 19-22)

4. Curved and polygonal forms. The profusion of circular and polygonal shapes in Coca is extraordinary; each wall is split and topped by towers with these geometries. Little polygonal towers called 'garitones' solve the problem of the transition in the corners of the long alignment of machicolations although they are ineffective for any defensive purpose. 
Buitrago parece proteger la naturaleza de la acción humana, cerrándose al lado humanizado de la carretera (también alamborándose con respecto a este nivel) y abriéndose hacia el valle, introduciendo el paisaje natural en el interior del edificio.

Esta estrategia se da en Cano desde sus primeras obras. Su propia Casa en $\mathrm{La}$ Florida (1955-1958), se cierra drásticamente a la calle con muros ciegos de ladrillo encalado y se abre buscando la relación interior-exterior más fluida posible con el jardín y los patios protegidos por la edificación. Es muy revelador de esta actitud el siguiente texto de Julio Cano, en el que nos cuenta algo similar a la conclusión de Cándido de Voltaire después de todas sus aventuras: "Mis aficiones principales han sido la historia, el dibujo y cultivar el jardín. Porque como amo la naturaleza, procuro no salir de casa, lo que aconsejo a todos los que de verdad la aman". (10) (Figs. 14-17)

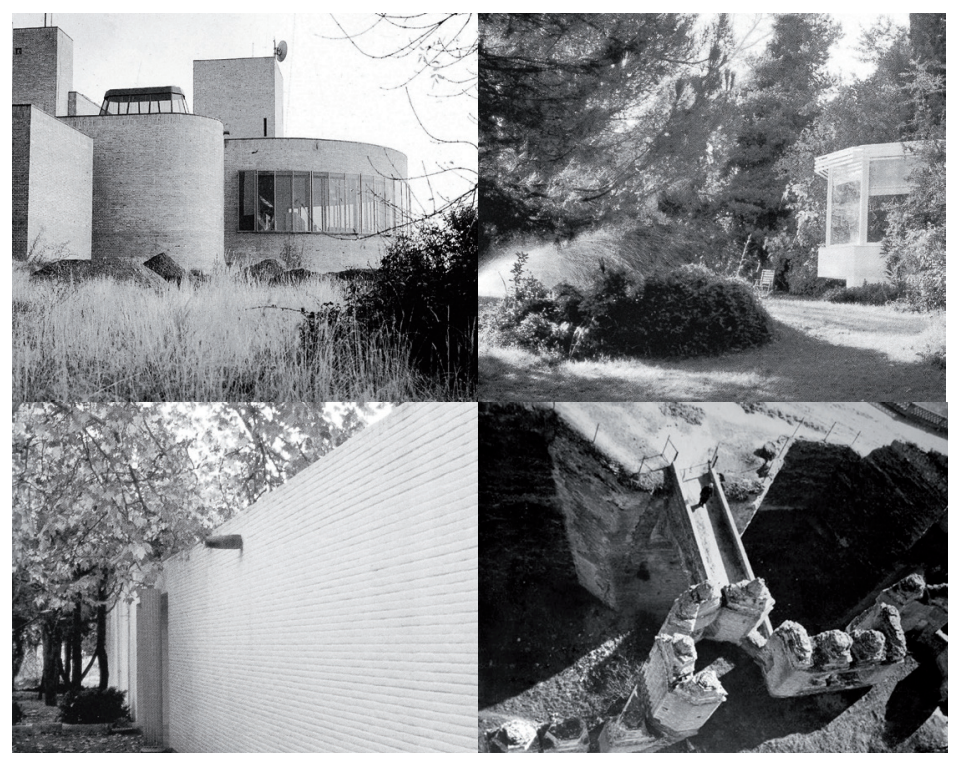

Figs. 14, 15. Comparativa de la sala de control de Buitrago e invernadero de la Casa Julio Cano.

Fig. 16. Muro encalado de la Casa Julio Cano, acceso al estudio.

Fig. 17. Puente de acceso al Castillo de Coca.

In Buitrago, these forms are shown, accordingly to a rationalist building, with all its abstract purity, fulfilling programmatic and functional requirements (panoramic view from the control room, end of the conference room and expression of the movement on the stairs and so on) and are resolved constructively with curve-shaped bricks as in Coca Castle. Polygonal form, the more expensive to solve in brick, is solved with glass, appearing in the window of the control room and in the skylights. (Fig. 23)

5. Ornamentation. In Coca Castle everything is lavishly decorated, leading the technical resources of Moorish ornamentation to their limit. This profusion of decoration makes it almost invisible, as a textured fabric overlay, approaching by its saturation to the nude and austere architectural character of Cano, with a continuous texture formed by the jointing of ceramic bricks.

The comparative study of the building of Buitrago de Lozoya and Coca Castle document one example -among many that can be found in the production of Cano Lasso- of the use of the reference as a tool for design. In this case we talk about the reference to the ruin, one of the most persistent reference constellations within the architect's work and immediately referring to nonlinear models of creation created as Aby Warburg's Atlas Mnemosyne, Walter Benjamin's Passagenwerk or Giulio Camillo's Theater of Memory. 
2. Los paramentos horizontales. En el edificio de Cano la unidad de material es extrema, ofreciendo un aspecto y una integración en el paisaje similar a los que ofrece el Castillo de Coca (aspecto que paradójicamente corresponde al de una ruina, ya que el castillo en su época tenía una apariencia muy diferente, debido a la profusión de ornamentación superpuesta a sus muros). Esta voluntad de resolver todos los paramentos con el mismo material se extiende tanto vertical como horizontalmente: "El principio de la unidad del material se siguió a rajatabla, llevando al límite de lo posible muros, pavimentos, escaleras". (11) (Fig. 18)

3. El patio. El patio de Coca, hoy inexistente, es descrito por Pascual Madoz: (12) "se componía de un patio cuadrado con una doble galería de columnas de mármol de orden corintio y compuesto, con los pisos y paredes cubiertas de azulejos". El patio principal de Buitrago, que sirve de residencia y centro de estudios es de una planta con galería perimetral acristalada. La estruc-

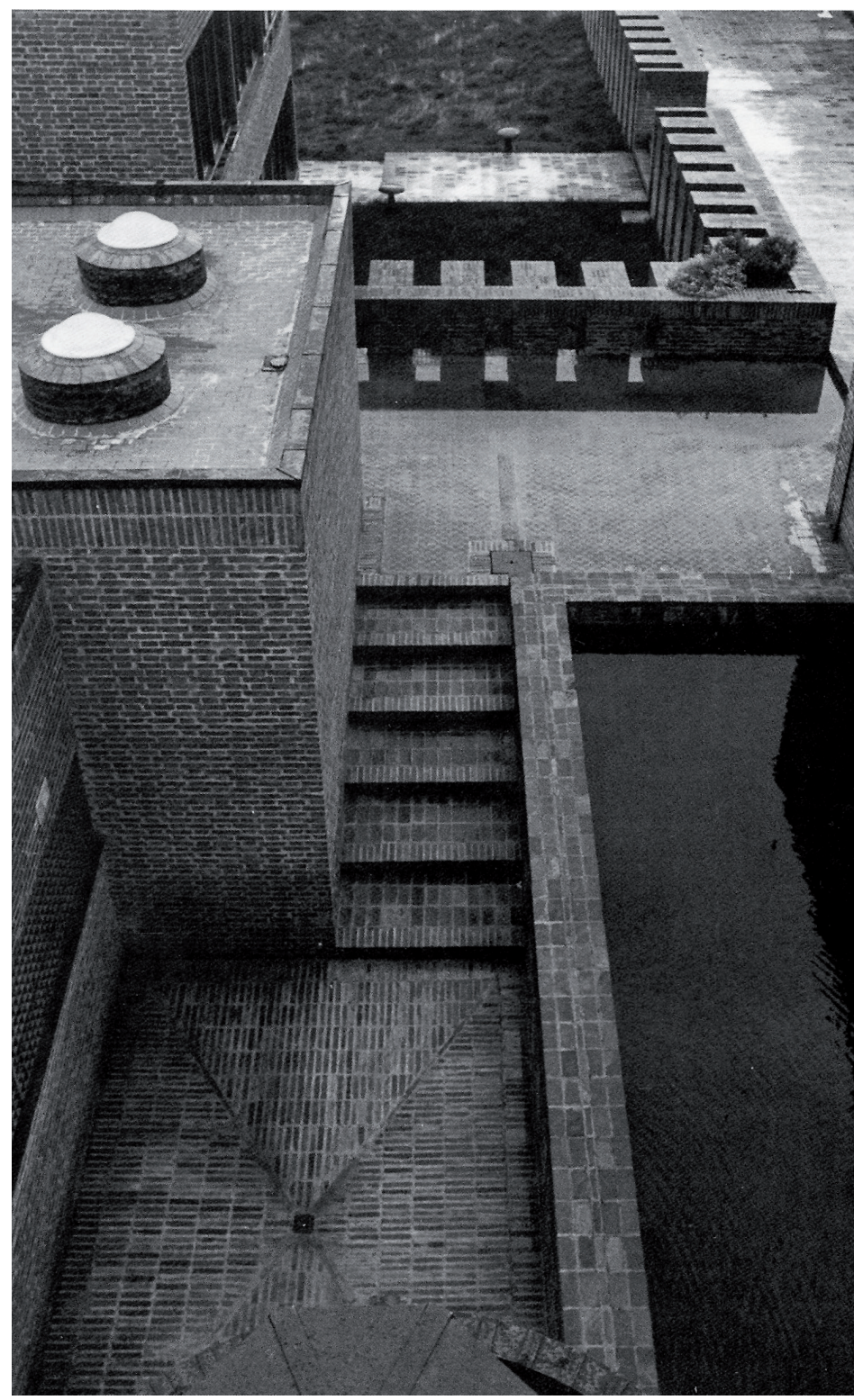

Fig. 18. Estación de Comunicaciones por Satélite de Buitrago de Lozoya. 


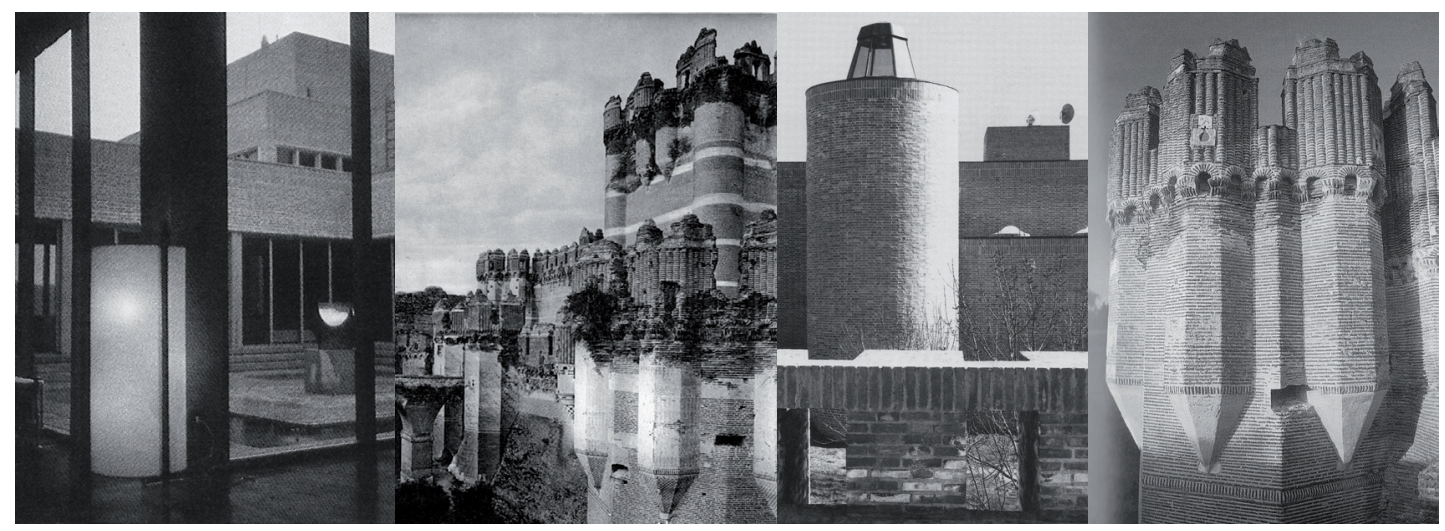

tura de perfiles metálicos forma parte del plano de cerramiento vítreo, casi confundiéndose con las líneas de carpintería vertical. (Figs. 19-22)

Fig. 19. Patio de la Estación en Buitrago de Lozoya.

Fig. 20. Castillo de Coca.

Figs.21, 22. Comparativa de las torres.

4. Forma curva y poligonal. La profusión de formas circulares y poligonales en Coca es extraordinaria, cada muro está dividido y rematado por torres con estas geometrías que soportan garitones poligonales que resuelven el problema de la transición en las esquinas de las matacanadas corridas, ineficaces para cualquier función defensiva.

En Buitrago, estas formas se muestran, como corresponde a un edificio racionalista, con toda su pureza abstracta, cumpliendo con requerimientos programáticos y funcionales (visión panorámica desde sala de control, remate de sala de conferencias, expresión de la circulación en las escaleras, etc.) y se resuelven constructivamente como en Coca con ladrillos aplantillados. La forma poligonal, más costosa de resolver en ladrillo, se reserva para el vidrio, apareciendo en el ventanal de la sala de control y en los lucernarios. (Fig. 23)

\section{REFERENCIAS}

\section{JULIO CANO LASSO. MONOGRAFÍAS}

Julio Cano Lasso. Revista Nueva Forma. n. 72-73, (Enero-Febrero 1972).

Julio Cano Lasso. Arquitecto. Xarait Ediciones, 1980.

Cano Lasso. Arquitecto. Fundación Camuñas, 1988.

El ladrillo material moderno. Federación española de Fabricantes de Ladrillo y Tejas de arcilla cocida. HISPALYT. 1988.

Julio Cano Lasso 1. Revista Arquitectos. n. 123. Consejo Superior de Arquitectos de España, 1991.

Julio Cano Lasso 2. Revista Arquitectos. n. 124. Consejo Superior de Arquitectos de España, 1991.

Julio Cano Lasso. Medalla de oro de la Arquitectura. Consejo Superior de Arquitectos de España, 1992.

Julio Cano Lasso. Estudio Cano Lasso. Madrid: Editorial Munilla-Lería, 1995.

Julio Cano Lasso-Estudio Cano Lasso. Milán: Editorial Electa, 1996.

\section{ESTACIÓN DE COMUNICACIONES POR SATÉLITE EN BUITRAGO}

Revista Arquitectura. n. 115, (Julio 1968).

Hogar y Arquitectura. n. 83, (Julio-Agosto 1969).

Construcciones en ladrillo. Barcelona: Gustavo Gili, 1970.

Arquitecture d'Aujourd'hui. Abril-Mayo 1970.

EL CASTILLO DE COCA. SEGOVIA.

AZCÁRATE, José María. Monumentos españoles. Tomo III. Madrid: Ministerio de Cultura, 1954.

GAMAZO, Conde de. Castillos en Castilla. Madrid, 1955

COOPER, Edward. Castillos señoriales en la Corona de Castilla. Salamanca: Universidad De Salamanca, Ediciones, 1992.

RODRÍGUEZ MARTÍNEZ, Felipe. 'Apuntes históricos sobre el castillo de Coca'. Revista Castillos de España. n.115, (Octubre 1999). MADOZ, Pascual. Diccionario geográfico-estadístico-histórico de España y sus posesiones en ultramar. 1847 


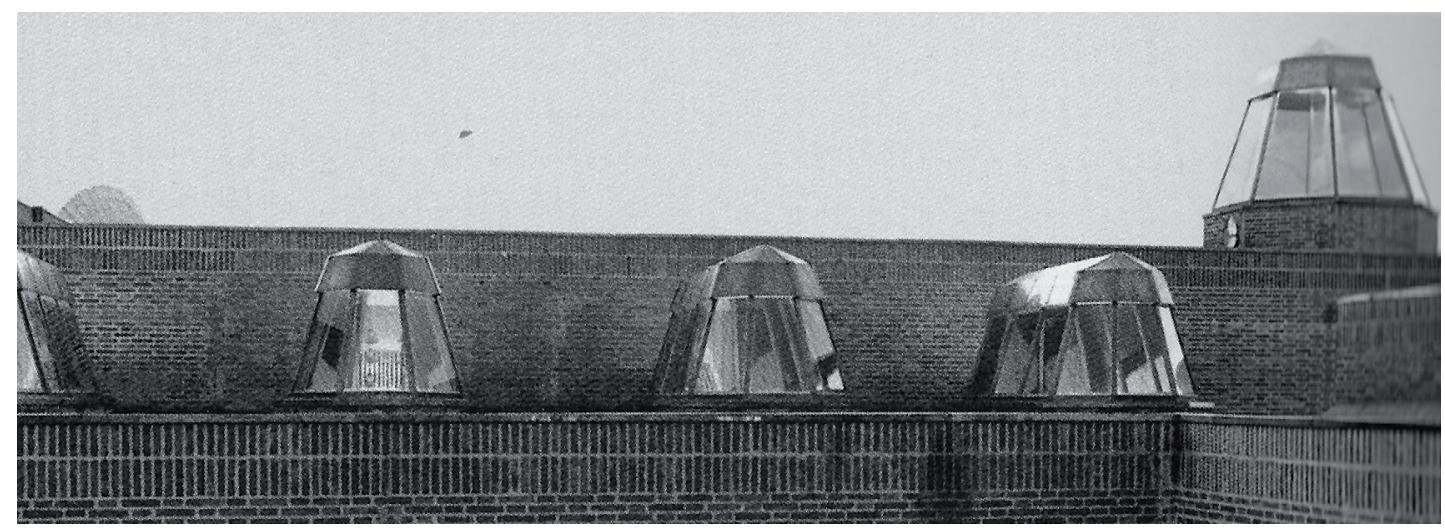

5. Ornamentación. En el castillo de Coca todo esta profusamente decorado, llevando al límite los recursos técnicos de la ornamentación mudéjar. Este Fig. 23. Lucernarios de la Estación de Comunicaciones por Satélite en Buitrago de Lozoya. todo continuo vuelve la ornamentación casi invisible, como un tejido texturado superpuesto, que se acerca por saturación al carácter de arquitectura no ornamentada de Cano, con una textura continua constituida por el llagueado del propio material cerámico.

El estudio comparado del edificio de Buitrago de Lozoya y el Castillo de Coca documenta un ejemplo, entre los muchos que se pueden encontrar en la producción de Cano Lasso, de la utilización de la referencia como instrumento de proyecto. Es en este caso, la referencia a la ruina una de las más persistentes constelaciones referenciales dentro de la obra del arquitecto y que remite inmediatamente a modelos no lineales de creación como el Atlas Mnemosyne de Aby Warburg, los PassagenWerk de Walter Benjamin o el Teatro de la Memoria de Giulio Camillo.

\section{REFERENCES}

\section{JULIO CANO LASSO. MONOGRAPHS}

Julio Cano Lasso. Revista Nueva Forma. n. 72-73, (Enero-Febrero 1972).

Julio Cano Lasso. Arquitecto. Xarait Ediciones, 1980.

Cano Lasso. Arquitecto. Fundación Camuñas, 1988.

El ladrillo material moderno. Federación española de Fabricantes de Ladrillo y Tejas de arcilla cocida. HISPALYT. 1988.

Julio Cano Lasso 1. Revista Arquitectos. n. 123. Consejo Superior de Arquitectos de España, 1991.

Julio Cano Lasso 2. Revista Arquitectos. n. 124. Consejo Superior de Arquitectos de España, 1991.

Julio Cano Lasso. Medalla de oro de la Arquitectura. Consejo Superior de Arquitectos de España, 1992.

Julio Cano Lasso. Estudio Cano Lasso. Madrid: Editorial Munilla-Lería, 1995.

Julio Cano Lasso-Estudio Cano Lasso. Milán: Editorial Electa, 1996.

\section{COMUNICATIONS STATION IN BUITRAGO}

Revista Arquitectura. n. 115, (Julio 1968).

Hogar y Arquitectura. n. 83, (Julio-Agosto 1969).

Construcciones en ladrillo. Barcelona: Gustavo Gili, 1970.

Arquitecture d'Aujourd'hui. Abril-Mayo 1970. 


\section{NOTAS}

1. Se usa la palabra 'poética' en la acepción de la R.A.E en su vigésimo primera edición: 4. f. Conjunto de principios o de reglas, explícitos o no, que observan un género literario o artístico, una escuela o un autor.

2. CAPITEL, Antón. 'Notas sobre la figura de Julio Cano Lasso en la arquitectura española', Revista Arquitectos. n.123, 1991. 3. FULLAOND0, Juan Daniel. 'En torno a Julio Cano Lasso', Nueva Forma. n. 72-73, (Febrero, 1972).

4. CANO LASSO, Julio. 'Mi visión de la arquitectura'. Colección Lecciones/documentos de arquitectura 2, T6 Ediciones, ETSAUN, Universidad de Navarra, 1997.

5. STRAVINSKI, Igor: Poética musical. Acantilado, 2006. 6. VAN EYCK, Aldo. 'El interior del tiempo'. CIRCO. La cadena de cristal. n. 37, 1996.

7. BORGES, Jorge Luis. 'Pierre Menard, autor del Quijote'. Ficciones. Seix Barral, 1986. 50 p.

8. Julio Cano Lasso: Estudio Cano Lasso. Editorial MunillaLería, 1995.

9. 'Estación de comunicaciones por satélite en Buitrago'. Revista Arquitectura. n. 115, (Julio, 1968).

10. CANO LASSO, Julio. 'La arquitectura del paisaje', Revista Arquitectos. n. 123, 1991.

11. CANO LASSO, Julio. 'Retorno al paraíso, utopía. Cano Lasso. 1949-1995. MOPU, 1995.

12. MADOZ, Pascual: Diccionario geográfico-estadístico-histórico de España y sus posesiones en ultramar, Tomo 6.1847.497 p.

\section{NOTES}

1. The word 'poetic' is used in the meaning of the RAE in its twenty-first edition: 4 . f. Set of principles or rules, explicit or not, observed by a literary or artistic genre, a school or an author.

2. CAPITEL, Antón. 'Notas sobre la figura de Julio Cano Lasso en la arquitectura española', Revista Arquitectos. n.123, 1991. 3. FULLAONDO, Juan Daniel. 'En torno a Julio Cano Lasso', Nueva Forma. n. 72-73, (Febrero, 1972).

4. CANO LASSO, Julio. 'Mi visión de la arquitectura'. Colección Lecciones/documentos de arquitectura 2, T6 Ediciones, ETSAUN, Universidad de Navarra, 1997.

5. STRAVINSKI, Igor: Poética musical. Acantilado, 2006.

6. VAN EYCK, Aldo. 'El interior del tiempo'. CIRCO. La cadena de cristal. n. 37, 1996.

7. BORGES, Jorge Luis. 'Pierre Menard, autor del Quijote'. Ficciones. Seix Barral, 1986. 50 p.

8. Julio Cano Lasso: Estudio Cano Lasso. Editorial MunillaLería, 1995.

9. 'Estación de comunicaciones por satélite en Buitrago'. Revista Arquitectura. n. 115, (Julio, 1968).

10. CANO LASSO, Julio. 'La arquitectura del paisaje', Revista Arquitectos. n. 123, 1991.

11. CANO LASSO, Julio. 'Retorno al paraíso, utopía'. Cano Lasso. 1949-1995. MOPU, 1995.

12. MADOZ, Pascual: Diccionario geográfico-estadístico-histórico de España y sus posesiones en ultramar, Tomo 6.1847. 497 p.

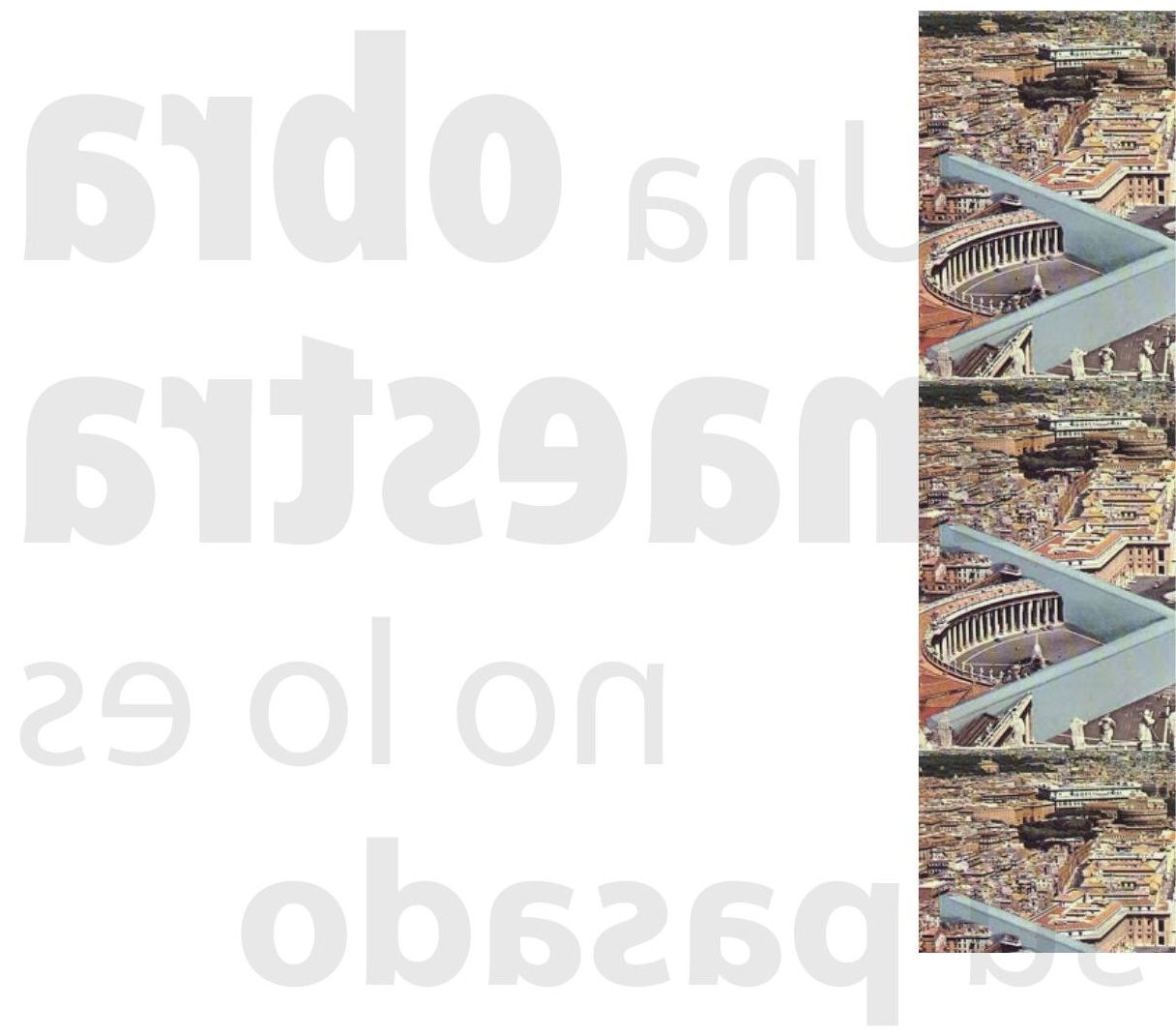

